\title{
Sistem Penjemur Pakaian Otomatis Menggunakan Raspberry Pi Berbasis Android
}

\author{
Putri Isma Oktawiani, I Ketut Gede Darma Putra, Kadek Suar Wibawa \\ Program Studi Teknologi Informasi, Fakultas Teknik, Universitas Udayana \\ Bukit Jimbaran, Bali, Indonesia, telp. (0361) 701806 \\ e-mail: ismaoktawiani07@gmail.com, darma.putra@unud.ac.id, \\ suarwibawa@yahoo.com
}

\begin{abstract}
Abstrak
Perubahan cuaca yang terjadi di Indonesia salah satunya disebabkan oleh pemanasan global. Dampak dari perubahan cuaca salah satunya dalam hal menjemur pakaian. Kekhawatiran tersebut bertambah ketika rumah dalam keadaan kosong, sedangkan jemuran yang digunakan untuk mengeringkan pakaian basah berada di luar rumah. Proses penjemuran pakaian yang bersifat manual membuat pengeringan pakaian menjadi tidak berguna ketika hujan turun. Proses penjemuran yang bersifat manual diperbarui dengan sentuhan teknologi Internet of Things guna mengoptimalkan proses penjemuran pakaian. Kelebihan teknologi Internet of Things yang diterapkan pada sistem penjemur pakaian menggunakan Raspberry Pi dipadukan dengan teknologi berbasis android. Sistem dilengkapi dengan stepper motor yang dapat memasukkan dan mengeluarkan pakaian sesuai dengan kondisi yang diterima oleh sensor. Fitur pada android dimanfaatkan sebagai media dalam melakukan controlling dan monitoring terhadap sistem penjemur pakaian. Sistem dilengkapi informasi cuaca yang memudahkan pengguna mengetahui kondisi cuaca terkini. Hasil penelitian yang dilakukan menunjukkan bahwa sistem controlling dan monitoring dapat dilakukan dengan menggunakan aplikasi android.
\end{abstract}

Kata kunci: Internet of Things, Jemuran Pakaian, Raspberry Pi, Android

Global warming is one factor causing weather change in Indonesia. One of its impacts is in terms of clothes drying. These concern increases when the house is empty, while the clothes being dried are still wet and located outside the house. The manual process of clothes drying sometimes is very bad when rain comes. The manual clothes drying is being updated with involvement of Internet of Things technology. This is done to optimize the clothes drying process. The advantage of Internet of Things technology applied to the clothes drying process is using Raspberry Pi combined with web and android technology. The system is equipped with a stepper motor that can move clothes in or out regarding the weather conditions received by the sensor. Features that exist on the android will be used as a medium to control and monitor the clothes drying process. The system also featured with forecast that can give information about the latest weather conditions. The result of this study shows that controlling and monitoring systems can do with android applications.

Keywords: Internet of Things, Clothesline, Raspberry Pi, Android

\section{Pendahuluan}

Pemanasan global yang sekarang sedang terjadi menyebabkan iklim di Indonesia menjadi kurang menentu, sehingga musim kemarau dan musim hujan sulit untuk diprediksikan lagi. Dampak dari permasalahan tersebut diantaranya sering terjadi perubahan cuaca seperti datangnya hujan atau rintik hujan secara tiba-tiba saat musim kemarau. Biasanya musim hujan terletak antara bulan Oktober sampai dengan Februari dan musim kemarau antara Maret sampai dengan September. Berdasarkan hasil pengolahan dan analisis data BMKG tahun 2018, prakiraan musim hujan tahun 2018 bila dibandingkan terhadap rata-ratanya selama 30 tahun (1981-2010) di 342 Zona Musim, awal musim hujan tahun 2018 sebagian besar daerah lebih maju bila dibandingkan dengan biasanya [1]. Prakiraan musim kemarau tahun 2018 bila dibandingkan terhadap rata-ratanya selama 30 tahun (1981-2010), awal musim kemarau 2018

Sistem Penjemur Pakaian Otomatis Menggunakan Raspberry Pi Berbasis Android $\quad 225$ (Putri Isma Oktawiani) 
sebagian besar daerah mundur jika dibandingkan dengan biasanya [1]. Terlihat dari data tersebut perubahan cuaca setiap tahunnya sulit untuk diprediksi.

Dampak dari permasalahan tersebut diantaranya sering terjadi perubahan cuaca seperti datangnya hujan atau rintik hujan secara tiba-tiba saat musim kemarau. Kekhawatiran tersebut bertambah ketika rumah dalam keadaan kosong, sedangkan jemuran yang digunakan untuk mengeringkan pakaian basah berada di luar rumah. Begitupula pada musim hujan, pakaian tidak kunjung kering karena hampir setiap hari turun hujan. Proses penjemuran pakaian yang bersifat manual membuat pengeringan pakaian menjadi sia-sia jika hujan turun secara tiba-tiba. Proses penjemuran yang bersifat manual mulai diperbarui dengan sentuhan teknologi Internet of Things guna mengoptimalkan proses pengeringan pakaian.

Penerapan teknologi Internet of Things (IOT) telah banyak dilakukan diantaranya adalah dalam penelitian yang berjudul "Perancangan Sistem Informasi Parkir dengan WiFi Berbasis Arduino" merupakan sistem informasi parkir menggunakan Microcontroller Wido yang mampu untuk memberikan informasi kepada pengguna mengenai keadaan tempat parkir secara real time [2]. Penelitian lainnya menggunakan konsep loT dengan menggunakan microcontroller berjudul "Automatic Protection of Clothes from Rain" merupakan sistem embedded yang terdiri dari microcontroller 8-bit untuk memantau adanya sinar matahari dan secara otomatis memasukkan kembali pakaian untuk melindungi dari basah pada saat hujan turun [3]. Kelemahan dari sistem yang pernah dibuat diantaranya pengguna belum dapat melakukan controlling dan monitoring secara real time, dan alat yang dirancang belum dapat berkomunikasi dengan device lainnya. Penelitian mengenai pembuatan aplikasi android yang berjudul "Aplikasi Pengontrol Robot Mobil Menggunakan Suara Berbasis Android" merupakan aplikasi pengontrol pergerakan robot mobil secara real-time dan dinamis menggunakan perintah suara dengan menggunakan android [4].

Teknologi Internet of Things yang diterapkan pada sistem penjemur pakaian menggunakan Raspberry Pi kemudian dipadukan dengan teknologi android [5]. Android akan dimanfaatkan dalam sistem penjemur pakaian sebagai media dalam melakukan controlling dan monitoring terhadap sistem penjemur pakaian. Sistem penjemur pakaian dilengkapi informasi cuaca yang memudahkan pengguna mengetahui kondisi cuaca terkini serta prakiraan cuaca dalam beberapa hari mendatang.

Sistem penjemur pakaian otomatis menggunakan teknologi Internet of Things dapat memudahkan pengguna dalam hal menjemur pakaian. Sistem penjemur pakaian membantu masalah yang terjadi pada cuaca yang tidak menentu, sehingga pengguna tidak perlu khawatir lagi terhadap pakaian yang dijemur baik pagi maupun malam hari. Sistem juga dilengkapi dengan motor stepper yang dapat memasukkan dan mengeluarkan pakaian sesuai dengan kondisi yang diterima oleh sensor. Sistem penjemur pakaian otomatis menggunakan teknologi Internet of Things juga diharapkan dapat menjadi sebuah sistem penjemur pakaian pintar guna memudahkan masyarakat dalam menjemur pakaian tanpa adanya tenaga manual.

\section{Metodologi Penelitian}

Metodologi Penelitian yang digunakan dalam proses pembuatan Sistem Penjemur Pakaian meliputi pencarian studi literatur, perancangan gambaran umum sistem dan diagram blok, pembuatan sistem, dan pengujian sistem dengan menggunakan aplikasi android.

\subsection{Gambaran Umum Sistem}

Sistem penjemur pakaian otomatis merupakan sistem berupa rangkaian perangkat keras dan perangkat lunak yang dapat melakukan kontrol dan monitor penjemur pakaian menggunakan aplikasi android. Kontrol penjemur pakaian berupa kontrol yang dapat memasukkan dan mengeluarkan pakaian menggunakan aplikasi android. Monitor penjemur pakaian merupakan fungsi agar kontrol yang digunakan dapat berjalan sesuai dengan kontrol pengguna maupun alat, yaitu monitor penggunaan sensor cahaya dan sensor hujan seperti pada Gambar 1. 


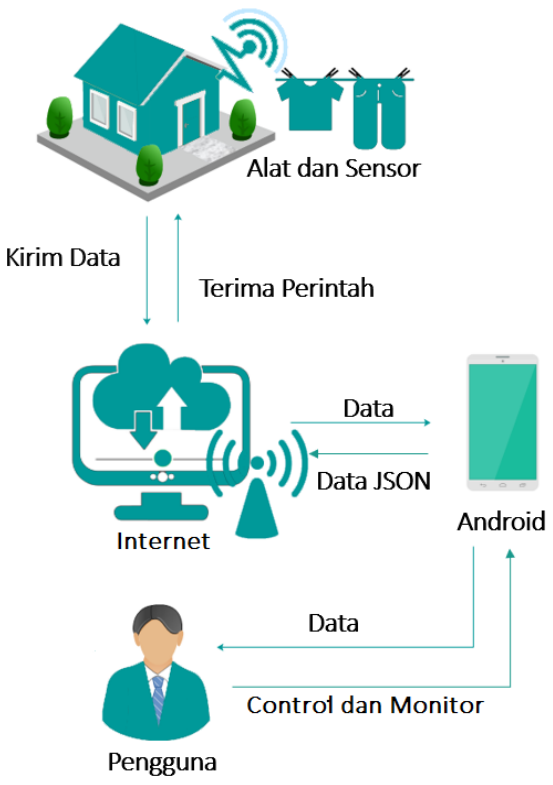

Gambar 1. Gambaran Umum Sistem

Penggunaan sensor cahaya dan sensor hujan seperti pada Gambar 1 dapat menjadi indikator intensitas cahaya, intensitas hujan, dan kondisi cuaca yang dapat dikirimkan secara langsung kepada Raspberry Pi untuk dilakukan pengambilan keputusan sehingga pakaian yang dijemur dapat terhindar dari hujan. Jemuran pakaian otomatis bekerja apabila sensor cahaya dan sensor hujan mendeteksi perubahan lingkungan sekitar. Kemudian hasil sensor tersebut diolah oleh Raspberry Pi yang digunakan untuk memasukkan dan mengeluarkan jemuran menggunakan motor stepper. Motor stepper berfungsi sebagai pengendali atau pengatur pergerakan dan arah putaran motor stepper. Motor stepper akan bekerja sesuai dengan kondisi yang telah ditentukan yaitu motor berputar ke kanan atau berputar ke kiri. Hasil data tersebut disimpan pada cloud dan dengan aplikasi android pengguna dapat melakukan monitoring alat berdasarkan data yang dikirim pada cluod. Server web memberikan layanan data dan menerima permintaan dari pengguna. Sama halnya dengan server web, server cuaca digunakan untuk memberikan layanan data berupa data cuaca yang di request oleh pengguna. Pengguna yang menggunakan sistem penjemur pakaian otomatis dapat melakukan controling dan monitoring penjemur pakaian pada aplikasi android yang berfungsi memberikan informasi intensitas cahaya, intensitas hujan, dan kondisi alat.

\subsection{Diagram Blok Sistem}

Gambaran umum sistem penjemur pakaian otomatis menggunakan teknologi Internet of Things dijelaskan dengan menggunakan diagram blok pada Gambar 2.

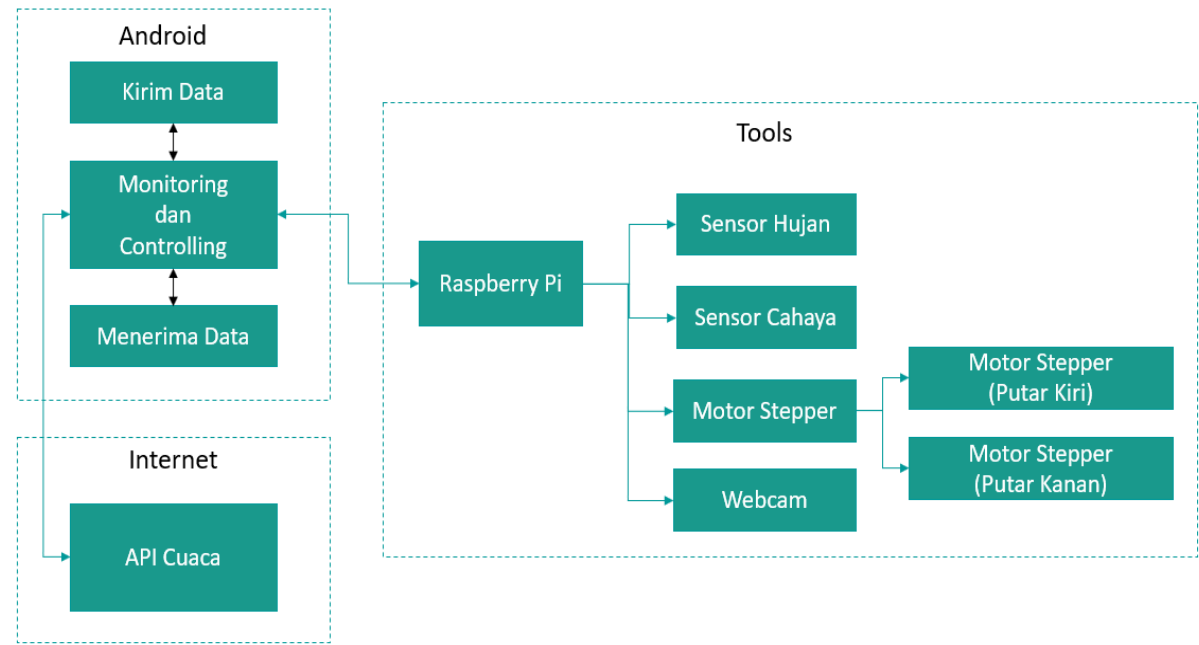

Gambar 2. Diagram Blok 
Blok Android pada Gambar 2 merupakan blok yang dapat mengirim dan menerima pesan dari Raspberry Pi. Android berfungsi melakukan kontrol dengan mengirimkan perintah melalui aplikasi dan melakukan monitor melalui data yang tersimpan pada server web. Blok Internet merupakan blok yang dapat mengambil informasi cuaca menggunakan API cuaca yang terdapat pada internet. Blok Alat merupakan blok utama yang memiliki fungsi untuk memasukkan, mengeluarkan jemuran, dan memberi informasi intensitas cahaya dan hujan disekitar alat. Raspberry Pi berfungsi sebagai otak pengendali dari jemuran yang memproses setiap masukan perintah dari android dan mengeksekusinya sesuai dengan instruksi program yang telah diatur.

\section{Kajian Pustaka}

Kajian pustaka memuat teori penunjang yang menjadi landasan teori untuk mendukung pembuatan sistem penjemur pakaian otomatis berbasis android yang meliputi Internet of Things, Raspberry Pi, dan Android.

\subsection{Internet of Things}

Menurut analisa McKinsey Global Institute, Internet of Things merupakan sebuah teknologi terbaru yang memungkinkan pengguna dapat menghubungkan mesin, alat, dan benda fisik lainnya dengan sensor jaringan dan aktuator untuk memperoleh data, sehingga memungkinkan mesin mendapatkan informasi baru yang diperoleh secara independen [6]. Penerapan arstitektur Internet of Things dalam sistem penjemur pakaian pada masing-masing layer yaitu perception layer yang berisi sensor cahaya, sensor hujan, dan kamera. Komponen yang termasuk dalam network layer yaitu Raspberry Pi 3 dengan model yang digunakan yaitu tipe B dan server web yang memiliki fungsi menyimpan data yang dikirimkan pada Raspberry $\mathrm{Pi}$. Implementasi arsitektur sistem middleware layer yaitu penggunaan kabel jumper, breadboard, dan internet sebagai layanan sinyal yang menjadi keperluan utama dalam membangun sistem penjemur pakaian otomatis. Komponen yang termasuk dalam application layer yaitu aplikasi berbasis android. Aplikasi android membantu untuk memudahkan pengguna dalam proses melakukan control dan monitoring terhadap sistem penjemur pakaian otomatis.

\section{2. $\quad$ Raspberry Pi}

Raspberry $\mathrm{Pi}$ merupakan komputer mini berukuran seperti kartu kredit yang dikembangkan oleh Raspberry Pi Foundation, Inggris. Komputer single board dikembangkan dengan tujuan untuk mengajarkan dasar-dasar ilmu komputer dan pemrograman untuk siswa sekolah di seluruh dunia. Mikrokontroler yang memiliki fisik seperti Arduino biasanya lebih dikenal untuk proyek-proyek prototyping, tidak demikian dengan Raspberry $\mathrm{Pi}$ yang sangat berbeda dari mikrokontroler pada umumnya, Raspberry $\mathrm{Pi}$ lebih seperti komputer bila dibandingkan dengan Arduino [7]. Jenis Raspberry Pi yang digunakan dalam pembuatan sistem penjemur pakaian yaitu Raspberry Pi 3 Model B yang merupakan generasi ketiga Rasberry Pi.

\subsection{Android}

Android merupakan subset perangkat lunak untuk perangkat mobile yang meliputi sistem operasi, middleware, dan aplikasi inti yang dirilis oleh Google [8]. Android adalah sistem operasi bergerak atau mobile operating system yang mengadopsi sistem operasi linux, namun telah dimodifikasi. Android diambil alih oleh Google pada tahun 2005 dari Android Inc sebagai bagian strategi untuk mengisi pasar sistem operasi bergerak [9]. Google mengambil alih seluruh hasil kerja android termasuk tim yang mengembangkan android. Android menawarkan Android SDK yang menyediakan alat dan API untuk pengembang aplikasi dengan menggunakan bahasa pemrograman Java [10] [11].

\section{Hasil dan Pembahasan}

Hasil dan pembahasan dalam sistem penjemur pakaian otomatis meliputi uji coba alat dan uji coba sistem. Kebutuhan perangkat keras dan perangkat lunak dalam pembuatan sistem terlihat pada Tabel 1. 
Tabel 1. (a) Kebutuhan perangkat keras, (b) Kebutuhan perangkat lunak

\begin{tabular}{ll}
\multicolumn{2}{c}{ (a) } \\
\hline Jenis Hardware & Jumlah \\
\hline Raspberry PI 3 & 1 Buah \\
Modul Sensor LDR & 1 Paket \\
& \\
Modul Sensor Hujan & 1 Paket \\
Motor Stepper & 1 Paket \\
Webcam & 1 Buah \\
Kabel Jumper & 1 Paket \\
\hline
\end{tabular}

\begin{tabular}{ll} 
& $(\mathrm{b})$ \\
\hline Jenis Software & $\begin{array}{l}\text { Software } \\
\text { Digunakan }\end{array}$ \\
\hline Sistem Operasi & $\begin{array}{l}\text { Windows 10, Raspbian } \\
\text { Bahasa }\end{array}$ \\
Python, Java, Java \\
Pemrograman & Script, PHP, HTML \\
Database & SQLYog \\
Remote & Putty, VNC Viewer \\
Browser & Google Chrome \\
Editor & Sublime Text 3 \\
\hline
\end{tabular}

\subsection{Uji Coba Alat}

Pengujian alat sistem penjemur pakaian merupakan pengujian yang dilakukan berdasarkan kondisi yang diterima oleh sensor.

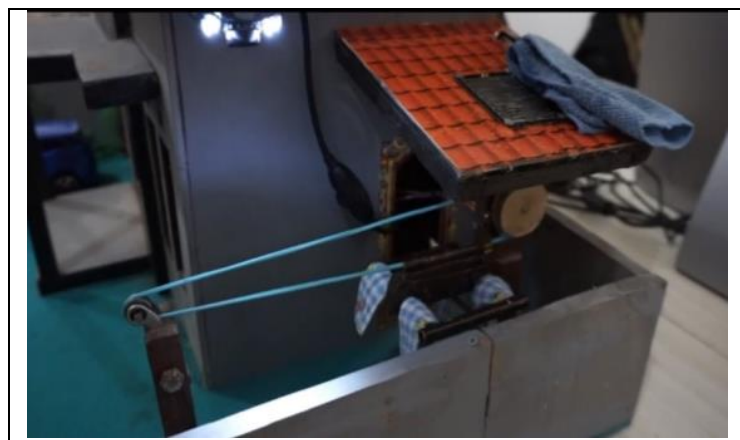

(a)

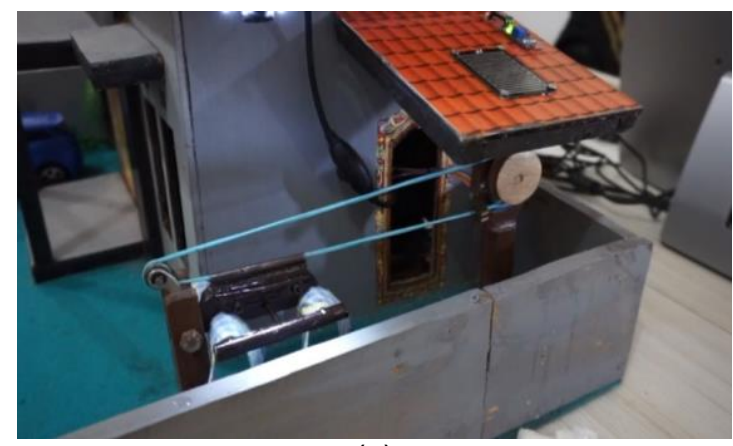

(c)

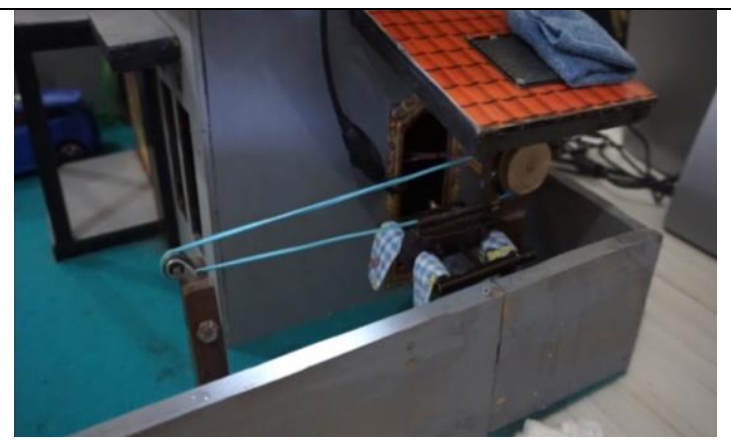

(b)

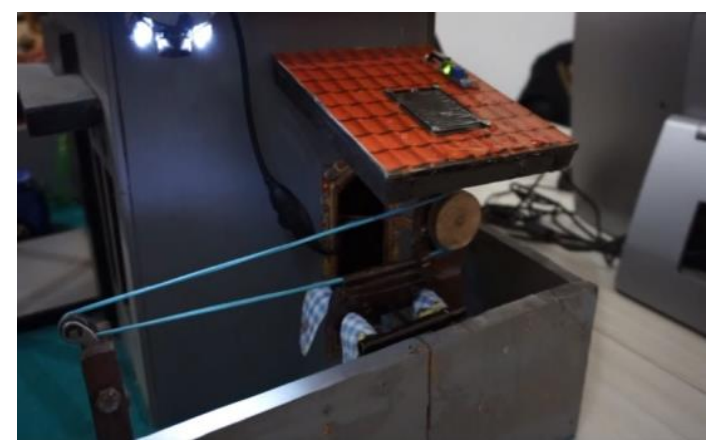

(d)

Gambar 3. (a) Uji Coba Menggunakan Kondisi I, (b) Uji Coba Menggunakan Kondisi II, (c) Uji Coba Menggunakan Kondisi III, (d) Uji Coba Menggunakan Kondisi IV

Uji coba ada Gambar 3(a) dilakukan pada Kondisi I yaitu sensor cahaya mendeteksi tidak ada cahaya dan sensor hujan mendeteksi ada hujan sehingga membuat jemuran masuk. Pengujian kedua pada Gambar 3(b) dilakukan pada Kondisi II yaitu sensor cahaya mendeteksi tidak ada cahaya dan sensor hujan mendeteksi tidak ada hujan sehingga membuat jemuran masuk. Pengujian ketiga pada Gambar 3(c) dilakukan pada Kondisi III yaitu sensor cahaya mendeteksi ada cahaya dan sensor hujan mendeteksi tidak ada hujan sehingga membuat jemuran keluar. Pengujian terakhir pada Gambar 3(d) dilakukan pada Kondisi IV yaitu sensor cahaya mendeteksi ada cahaya dan sensor hujan mendeteksi ada hujan sehingga membuat jemuran masuk. Pengujian sensor cahaya dilakukan dengan bantuan senter dengan ukuran cahaya dihitung menggunakan lux meter dan pengujian sensor hujan dilakukan dengan meneteskan beberapa air pada sensor. 


\subsection{Uji Coba Sistem}

Pengujian sistem dilakukan dengan beberapa kondisi yang ada. Pengujian pertama yaitu pengguna melakukan login terhadap sistem. Apabila pengguna berhasil login ke dalam sistem terlihat pada Gambar 4.

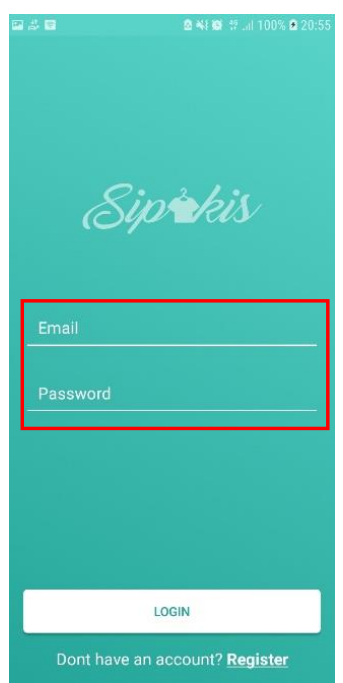

(a)
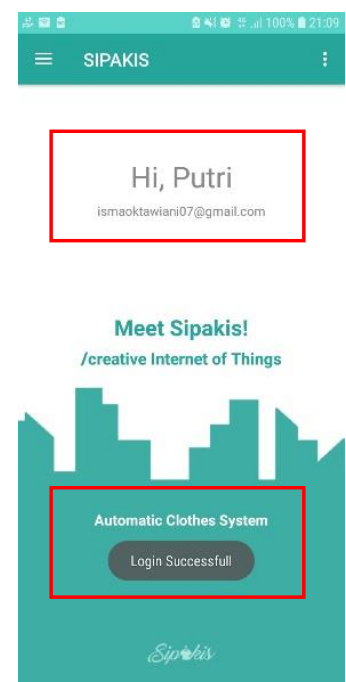

(b)

Gambar 4. (a) Tampilan Halaman Login, (b) Pengujian Login

Pengguna aplikasi dapat menggunakan sistem apabila melakukan login terlebih dahulu dengan memasukkan username dan password pada Gambar 3(a). Apabila pengguna berhasil login seperti Gambar 4(b), sistem akan menampilkan "Login Successful" pada aplikasi android. Pengguna akan mendapat informasi email yang digunakan untuk login dan first name yang didaftarkan pada sistem. Pengujian selanjutnya adalah melakukan monitoring secara otomatis terhadap alat pada Gambar 5.

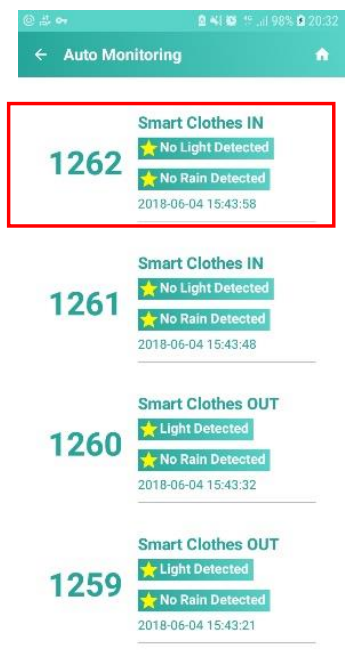

(a)

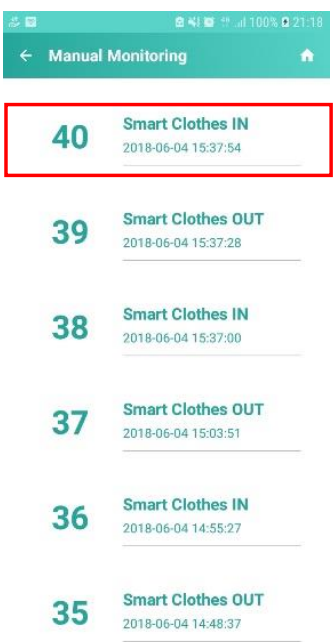

(b)

Gambar 5. (a) Tampilan Monitoring Data Otomatis, (b) Tampilan Monitoring Data Manual

Informasi mengenai posisi kondisi alat yang dibuat dalam bentuk list view seperti kondisi sensor cahaya, kondisi sensor hujan, posisi alat, dan waktu pengiriman data seperti pada Gambar 5(a). Informasi monitoring data manual berisi posisi alat dan waktu pengiriman data pada Gambar 5(b). Pengujian selanjutnya adalah melakukan controlling secara manual terhadap alat pada Gambar 6. 


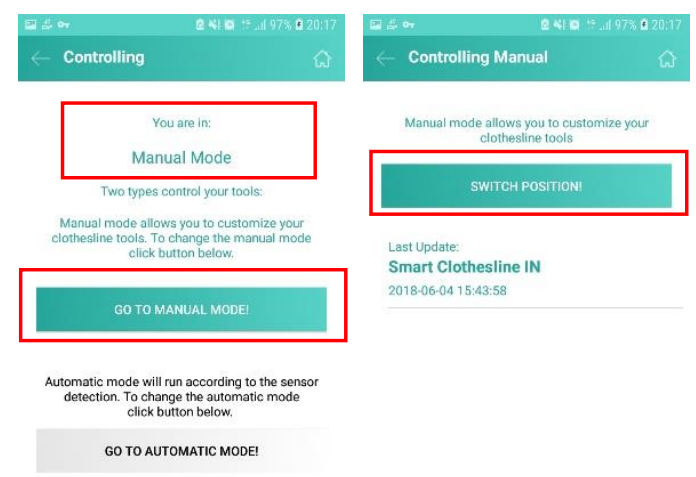

(a)

(b)

Gambar 6. (a) Tampilan Controlling Data, (b) Tampilan Controlling Data Manual

Tampilan Gambar 4.33 merupakan tampilan apabila pengguna memilih menu controlling. Terdapat dua mode yang digunakan pada aplikasi yaitu mode manual merupakan mode yang memungkinkan pengguna untuk mengatur IN atau OUT penjemur pakaian. Mode automatic merupakan mode yang memungkinkan sistem berjalan sesuai dengan kondisi pada sensor. Apabila pengguna menekan button manual mode, maka pengguna akan masuk ke halaman manual mode seperti pada Gambar 6(b), pengguna dapat melakukan kontrol alat yaitu memasukkan dan mengeluarkan pakaian sesuai dengan kondisi dengan menekan button switch position. Pengujian selanjutnya adalah melakukan controlling terhadap gambar yang terlihat seperti pada Gambar 7.

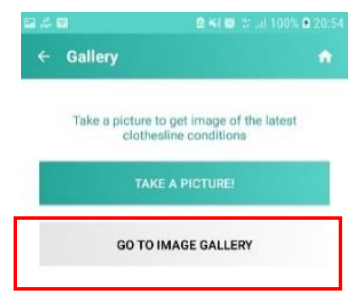

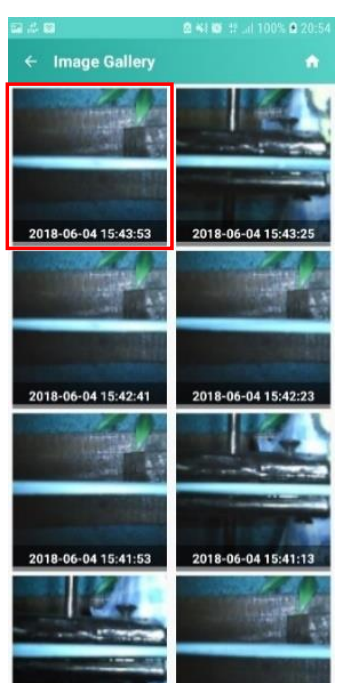

(b)

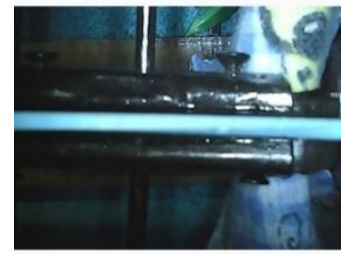

(c)

Gambar 7. (a) Tampilan Utama Gallery, (b) Tampilan Gallery Listview, (c) Fullscreen Image

Tampilan utama menu gallery pada Gambar 7(a) memungkinkan pengguna untuk melihat gambar dan mengambil gambar dari kamera yang dipasang pada prototype penjemur pakaian. Pengguna dapat memilih button take a picture, maka sistem mengirimkan request terhadap alat untuk mengambil gambar. Apabila pengguna ingin melihat hasil dari pengambilan gambar maka pengguna dapat menekan button image gallery seperti pada Gambar 7(b). Tampilan gambar secara fullscreen dapat dilihat pada Gambar 7(c). Pengujian terakhir menunjukkan notifikasi yang diterima sistem seperti pada Gambar 8. 


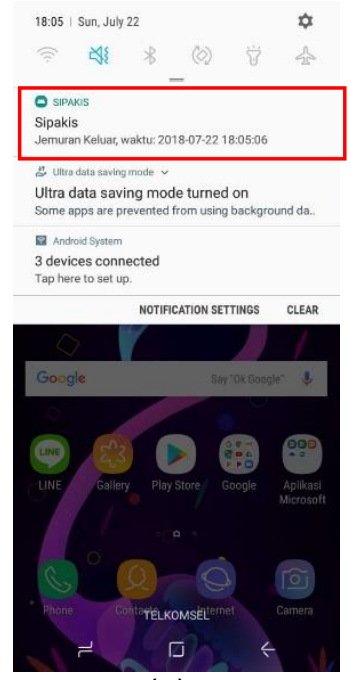

(a)

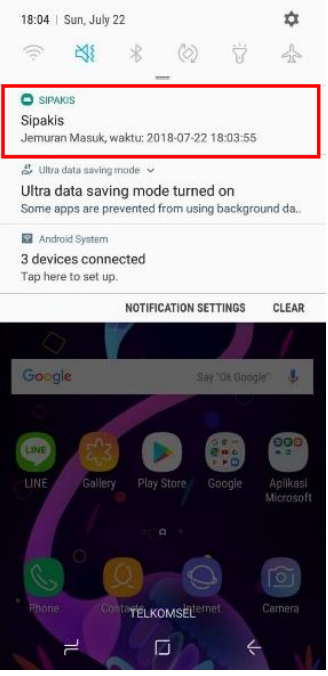

(b)

Gambar 8. (a) Notifikasi jemuran keluar, (b) Notifikasi jemuran masuk

Notifikasi pada Gambar 8(a) dan 8(b) terlihat apabila alat dalam perubahan posisi dari yang sebelumnya. Notifikasi alat ini memberikan informasi kondisi alat terakhir dan waktu perubahan posisi alat. Notifikasi pada Gambar 8(a) menunjukkan jemuran dalam kondisi keluar. Notifikasi pada Gambar 8(b) menunjukkan jemuran dalam kondisi masuk.

\section{Kesimpulan}

Sistem penjemur pakaian dibangun berbasis android yang mencakup proses monitoring dan controlling. Sistem penjemur pakaian otomatis dibuat menggunakan Raspberry $\mathrm{Pi}$, motor stepper, sensor cahaya, sensor hujan, dan kamera. Raspberry Pi digunakan sebagai alat utama yang berfungsi memerintahkan sistem untuk menyalakan, mematikan, dan memantau penjemur pakaian. Sistem penjemur pakaian dilengkapi dengan motor stepper yang dapat memasukkan dan mengeluarkan pakaian sesuai dengan kondisi yang diterima oleh sensor. Pengujian sistem dilakukan menggunakan aplikasi berbasis android. Hasil dari pengujian yang dilakukan menunjukkan bahwa sensor cahaya maupun sensor hujan mampu mendeteksi adanya cahaya atau adanya hujan dengan baik. Kegagalan sistem penjemur pakaian biasanya terletak pada permasalahan koneksi internet yang menyebabkan pengiriman data sensor tidak berhasil terkirim dengan baik.

\section{Daftar Pustaka}

[1] BMKG. "Prakiraan Musim Kemarau Tahun 2018 di Indonesia," 2018. Diakses tanggal 2 Juli 2018

[2] Novi Yulianto, and F. Bacharuddin, "Perancangan Sistem Informasi Parkir dengan WiFi Berbasis Arduino", Lontar Komputer., vol. 7, no. 3, pp. 132-137, 2016

[3] Prabhakar Hegade, S. N., Parashuram Alagundi, and Kiran M R. "Automatic Protection of Clothes from Rain." International Journal of Advanced Research in Computer and Communication Engineering 05(04): pp 363-366.

[4] I. P. Aix Cendana, AA. K. A. Cahyawan Wiranatha, and K. Suar Wibawa, "Aplikasi Pengontrol Robot Mobil Menggunakan Suara Berbasis Android," Merpati, vol. 5, pp. 110, 2017.

[5] M. G. Arsawiguna, A. A. K. Agung, C. Wiranatha, and K. S. Wibawa, "Rancang Bangun Aplikasi Game Tajen Berbasis Android menggunakan Artificial Intelligence", Lontar Komputer, vol. 6, no. 2, pp. 84-95, 2015.

[6] Agus Eka Pratama I Putu, Suakanto Sinung. Wireless Network Sensor Bandung: Informatika Bandung. 2015. 230-231.

[7] Dodit Suprianto, R. Agustina. Pemrograman Aplikasi Android. Yogyakarta: MediaKom. 2012. 
[8] N. K. A. W. Harmandya, Mentari, G. M. Arya Sasmita, "Rancang Bangun Aplikasi Tryout Ujian Nasional Sekolah Menengah Pertama (SMP) Berbasis Android," Lontar Komputer., vol. 6, no. 2, pp. 108-119, 2015

[9] N. K. A. Anggraeni, I. P. A. Bayupati, and I. M. Sukarsa, "Rancang Bangun Aplikasi Pembaca SMS Berbahasa Indonesia Berbasis Android," Merpati, vol. 5, pp. 228-238, 2017.

[10] A. F. Waruwu, I. P. A. Bayupati, and I. K. G. Darma Putra, "Augmented Reality Mobile Application of Balinese Hindu Temples: DewataAR," I. J. Comput. Netw. Inf. Secur., vol. 2, no. January, pp. 59-66, 2015.

[11] N. L. P. Pravina, A. A. K. Oka Sudana, and A. A. K. A. Cahyawan, "Implementation of MVC (Model-View-Controller) Architectural to Academic Management Information System with Android Platform Base," International Journal of Computer Applications (0975 - 8887), vol 57, no.8, November, 2012. 